\title{
Trust in government: What's news media got to do with it?
}

\author{
Frank Marcinkowski, Heinrich Heine University Düsseldorf, Department of Social Sciences* \\ Christopher Starke, Heinrich Heine University Düsseldorf, Department of Social Sciences \\ ${ }^{*}$ Corresponding author: Frank.Marcinkowski@phil.hhu.de
}

\begin{abstract}
In modern democracies, trust in government is a key indicator of political legitimacy and stability. Drawing from theories of media effects, we investigated whether using traditional media has a negative (media malaise hypothesis) or a positive (virtuous circle hypothesis) impact on trust in the national government. We used a serial mediation model involving evaluations of politicians and evaluations of the political process as mediators of how political communications influence trust in government. To test the model empirically, we conducted an online survey among 1115 respondents in Germany. Results suggest that the use of traditional media to access political information has a direct positive impact on trust in government mediated by people's evaluations of politicians and of the political process. We also found a positive serial mediation effect of using traditional media on trust in government mediated first by evaluations of politicians and second by evaluations of the political process.
\end{abstract}

\section{Keywords}

Trust in government, media effects, politicians, political Processes, quantitative survey, mediation effects

\section{Introduction}

In modern democracies, the amount of trust that people place in politics is a key indicator of political legitimacy and stability (Aarts, Fladmoe, \& Strömbäck, 2012; Easton, 1965). Consequently, the substantial decline of political trust in Western democracies since the 1960s poses considerable reason for concern (Hetherington, 2005; Torcal, 2014). Although some authors have viewed the trend as a chance to raise a "new generation of critical citizens" (Marien \& Hooghe, 2011, p. 267), most scholars have highlighted the detrimental effects of such eroding levels of political trust. The dominant view in the debate maintains that political distrust decreases voter turnout (Grönlund \& Setälä, 2007) and fosters support for populist parties (Billiet \& De Witte, 1995; Pauwels, 2011). Since mass media remain the primary source of political information in Western-type democracies, their importance as generators and inhibitors of political trust has been widely recognized in political communication research. In litera- ture on the topic, two opposing concepts characterize the effects of media use on political trust. On the one hand, the media malaise hypothesis posits that negative media content and its lack of substance cultivate public mistrust in politics (Capella \& Jamieson, 1997; Robinson, 1976). On the other, scholars have argued that the relationship between media exposure and political trust can be conceived as a virtuous circle (Norris, 2000), in which people with higher levels of political interest use a variety of media sources and thereby develop increased trust in politics. Empirical evidence for both claims has yielded inconclusive results. However, at times when the term "Lügenpresse» ("lying press") is chanted in public demonstrations and even named the official "non-word of the year" in Germany, insights about the consequences of media use on political attitudes are needed more than ever.

In response, we examined trust in government by conducting an online survey in order to extend current literature on the topic in two important dimensions. In what follows, we first introduce and re- 
port an outcome-based measurement for trust in government. Second, we discuss various mediation effects that we conceptualize as trust reasons -that is, reasons for trusting one's national government (Kohring \& Matthes, 2007). Ultimately, we propose a serial mediation model running from respondents' media use for political information, through their evaluations of politicians and evaluations of the political process to their trust in government. To test our hypotheses, we conducted an online survey among 1115 respondents in Germany.

\section{Trust in government}

Because trust is a broad, multifaceted construct, scholars have developed and extended several concepts to shed light on the objects of political trust. At base, political trust refers to "a basic evaluative or affective orientation toward the government" (Miller, 1974, p. 952). To date, however, in exactly whom or what people essentially trust when discussing political trust remains controversial (Catterberg \& Moreno, 2005; Wong, Wan, \& Hsiao, 2011). According to Owen and Dennis (2001), the various objects of political trust include national legislatures (Hibbing \& Theiss-Morse, 1995), presidential incumbents (Citrin \& Green, 1986), national and local governments (Levi \& Stoker, 2000; Ulbig, 2008), political institutions (Zmerli \& Newton, 2008), and the political system as a whole (Gamson, 1968). Imagining less distinction among objects of trust, research stemming from the European Social Survey and European Values Survey often merges trust in government, parliament, the legal system, and the police into the single concept of institutional trust (Grönlund \& Setälä, 2007; Hooghe \& Marien, 2012; Marien \& Hooghe, 2011). Early on, Citrin (1974) suggested subdividing political trust by discriminating attitudes affiliated with mistrust, including dissatisfaction with current government policy positions, dissatisfaction with the outcomes of ongoing events and policies, mistrust of incumbent officeholders, and the rejection of the entire political system. Decades later, Hetherington (1998, p. 792) developed that distinction by arguing that political trust consists of support for "regime-level political objects regardless of performance," or diffuse support, as well as support for political incumbents, or specific support (Easton, 1965). Nevertheless, literature addressing political trust remains divided regarding the objects of political trust. Consequently, as Torcal (2014, p. 1544) has observed, the interchangeable conceptualization of political trust and trust in government "is responsible for the traditional confusion between satisfaction with incumbents (political satisfaction) and political trust in the system." Drawing from that argument, we examined the specific form of trust that citizens place in their national government.

Trust in government, like any form of trust, is based on expectations about the future. As such, it encourages citizens to make risky investments in the future today. For instance, trust in government enables citizens to delegate political power to individual political actors whom they do not know personally via the concept of the sovereignty of the people. By actively supporting or at least accepting an incumbent government, citizens entrust authority over state affairs and even parts of their income in the form of taxes to a rather small group of politicians without being able to effectively assess their job capability in advance (Levi \& Stoker, 2000). For citizens to do so, not only legal compulsion but also trust is paramount. This investment is risky because citizens cannot be sure that the entrusted resources, such as political power and money, will be used responsibly, that is, in accordance to personal or societal hopes, wishes, and needs. Citizens are well aware that democratic decision making is highly contingent upon various conditions and that political promises are often broken after elections. Eroding levels of political trust therefore arguably reduce voter turnout in elections (Grönlund \& Setälä, 2007; Shaffer, 1981), discourage institutionalized political participation (Hooghe \& Marien, 2012), undermine the public's willingness to pay taxes and less- 
en their compliance with laws (Marien \& Hooghe, 2011), and spur voting for extreme right and populist parties (Billiet \& De Witte, 1995; Pauwels, 2011).

As Miller and Listhaug have observed, citizens base their political actions on "evaluations of whether or not political authorities and institutions are performing in accordance with normative expectations held by the public" (1990, p. 358). Accordingly, any comprehensive conceptualization of trust in government needs to specify those normative expectations -that is, what citizens refer to when they say that they trust or distrust the government. They added, however, that trust in government is rarely absolute (e.g., blind trust) and, more often than not, refers to context-specific expectations (Miller \& Listhaug, 1990). By analogy, a patient trusts his or her doctor to cure diseases but not to solve other personal problems; likewise, citizens trust the government not in general but, on the contrary, to take specific action in the future. In line with "extant research (...) using policy outcomes as the implicit object of citizens' trust" (Gershtenson \& Plane, 2007 , p. 5), we argue that people ultimately place their trust in the outcomes of political decision making, such as personal freedom, peace, economic wealth, social welfare, and a healthy natural environment. By extension, we propose that individuals' expectations about future policy outcomes form the core of political trust (Citrin \& Muste, 1999; Listhaug, 1995). We therefore use Hetherington's (2005, p. 9) definition of trust in government "as the degree to which people perceive that government is producing outcomes consistent with their expectations."

Such expectations are based on individuals' experiences and observations as well as different kinds of secondhand information. Personal, everyday experiences with political decisions such as energy prices or tax policies, of course, strongly shape people's expectations for future political outcomes. Thus, we expect mediated secondhand information about political outcomes to bear only slight direct effects upon people's trust in government. However, we also argue that mediated in- formation about political personnel (Citrin \& Luks, 1999; Miller \& Borrelli, 1991; Seyd, 2015) and political processes (Miller \& Listhaug, 1990; Owen \& Dennis, 2001) that enable political outcomes influence people's trust in government as well. Regarding the role of individual actors in cultivating trust in abstract social systems, Giddens (1990, p. 85) has argued that connections formed via such so-called facework connections "carry a reminder that it is flesh-and-blood people (...) who are its [the system's] operators." For instance, even though past experiences might not give citizens reason to expect tax reductions, they could nevertheless expect such reductions because they believe current political personnel to be more competent, more intelligent, more courageous, or more honest than their predecessors. Furthermore, scholars have argued that trust in government stems from people's perceptions of political institutions and processes (Kong, 2014; Lühiste, 2006; Miller \& Listhaug, 1990). From that perspective, output performance depends on special qualities of the input structure of political systems. For instance, if citizens perceive political processes to be fair, transparent, and responsive, then they consequently expect the government to produce better political outcomes. Thus, evaluations of both politicians and political processes shape individuals' expectations about beneficial political outcomes in the future.

In sum, traditional conceptualizations of trust in government have failed to isolate the very core of trust: expectations about the outcomes of future actions of public trustees. Instead, they have compounded trust-related beliefs and supporting ideas into a single concept that fails to conclusively conceive the trust-building process, as well as the role of news media therein. In response, we argue that expectations about future policy outcomes are the object of people's trust in government. We conceptualize all factors that build and shape those expectations - most notably, citizens' evaluations of politicians and political processes - as reasons for trust. Last, we hypothesize that people's chief sources of information about political actors and 
processes are either personal experiences or mediated communication that provides secondhand information. In the following section, we discuss major consequences of news media environments for people's perceptions of politics.

\section{Media effects}

Most literature addressing media effects on political trust (Avery, 2009; Strömbäck, Djerf-Pierre \& Shehata, 2015) has been situated within the debate about whether using news media ultimately decreases trust in politics (i.e., the media malaise hypothesis, Robinson, 1976) or increases it (i.e., the virtuous circle hypothesis, Norris, 2000). On the one hand, the media malaise hypothesis claims that reliance on TV news, its questionable credibility, and its tendency to stress negative aspects of politics (e.g., conflicts and scandals) have contributed to the decrease of political trust since the 1960s. On the other, Norris (2000) has argued that trust in politics and media exposure is best characterized by a circular relationship. In a cross-national analysis, she found that people with greater trust and interest in politics tended to access various media sources, which further increased their political trust and interest in politics, whereas the politically disinterested and distrusting did not pay attention to the news media in the least (Norris, 2000). To avoid confusion with overlapping concepts (e.g., trust in institutions), we review only literature specifically addressing trust in government.

To date, empirical studies investigating how using news media influences trust in government have yielded inconclusive results. Whereas some studies have suggested that accessing various kinds of news media, especially on TV, negatively affects trust in government (Avery, 2009; Mutz \& Reeves, 2005; Pietsch \& Martin, 2011; Tsfati, Tukachinsky, \& Peri, 2009; Valentino, Beckmann \& Buhr, 2001), others have indicated its positive influence (Moy \& Pfau, 2000; Norris, 2000) or else its lack of any significant effect whatsoever (Bennett, Rhine, Flickinger \& Bennett, 1999; Moy \&
Scheufele, 2000). From another angle, some authors have also reported conditional effects according to news source (Avery, 2009) or effects of a source's ideological leaning and the ideological views of each citizen (Ceron \& Memoli, 2015). The ambiguity of such results could derive from the trend that most studies either focus on a single medium or compare the impacts of different media with each other. However, other scholars have posited that media users typically do not access only newspapers, only TV news media, or only the internet to receive political information but instead "combine different media contacts into a comprehensive pattern of exposure" (Hasebrink \& Popp, 2006, p. 369; cf. Hasebrink \& Domeyer, 2012; Taneja, Webster, Malthouse \& Ksiazek, 2012; Yuan, 2011). That strand of literature argues that studies focusing on a single type of media could over- or underestimate the media effect. For instance, if watching TV news negatively influences the viewer's trust in government but reading the newspaper has a positive influence, the effects could cancel each other out if respondents use both sources to access political information. To account for such effects among media users, we investigate the impact of media use in general terms by asking the following research question:

, RQ: To what extent does the use of traditional media to access political information directly affect trust in government?

Given the mentioned theoretical reasons, we expect to detect indirect effects of media use on trust in government mediated by two sets of trust reasons. First, we hypothesize that evaluations of political decision makers, especially influential national-level politicians often covered by news media, act as crucial predictors of trust in government. To explain, as the personalization hypothesis suggests, individuals instead of parties or institutions have become more important in political communication (Van Aelst, Sheafer \& Stanyer, 2012). Moreover, as empirical studies have indicated, public perceptions of politi- 
cians are increasingly based on their individual characteristics such as competence, integrity, empathy, and charisma (Hellweg, Dionisopoulos \& Kugler, 1989) instead of their political stances or party affiliations (Balmas \& Sheafer, 2013; McAllister, 2007). Since most citizens lack direct personal contact with politicians, news media provide important information that shapes their opinions about politicians' individual characteristics. However, the question of whether news media negatively or positively influence evaluations of politicians remains disputed. Some findings indicate a positive relationship (Kim \& Kim, 2012), whereas others suggest that media use prompts more negative evaluations of politicians' character traits (Baumgartner \& Morris, 2006; Mutz \& Reeves, 2005). By contrast, some scholars have argued that "media use can induce positive or negative evaluations of political leadership based on the tone in which media reports describe the issues" (Camaj, 2014, p. 190; cf. Kim \& McCombs, 2007). Some studies investigating the nonverbal behavior of politicians have suggested that exposure to TV, as image-based media, can influence viewers' evaluations of character traits (Bucy, 2000; Haumer \& Donsbach, 2009). Given such inconclusive empirical evidence regarding whether the hypothesized mediation effect is positive or negative, we formulated our first hypothesis:

, H1: The use of traditional media to access political information indirectly affects trust in government mediated by evaluations of politicians.

The second set of trust reasons concerns perceptions of the political process. We hypothesize that people's assessments of fundamental democratic concepts such as responsiveness, transparency, and procedural justice increase their level of trust in government (Camaj, 2014). Those perceptions, in turn, are affected by people's news media use (Camaj, 2014; Floss, 2008; Sadri \& Flammia, 2014). Empirical studies investigating media effects on perceptions of democratic institutions and processes have generated inconclusive results. For instance, Camaj (2014, p. 187) posits that "the most important dimension of political trust is media priming of institutional efficiency and honesty." Furthermore, the results of Moy and colleagues indicate that media use has a positive influence on the perception of some institutions and processes and a negative influence on others (Moy \& Pfau, 2000; Moy, Pfau \& Kahlor, 1999). Taken together, those arguments inform our second hypothesis:

, H2: The use of traditional media to access political information indirectly affects trust in government mediated by evaluations of political processes.

Last, drawing from the argument that political discourse increasingly centers on political personalities, we hypothesize that people's evaluations of politicians also shape their evaluations of political processes. If people generally consider that politicians act responsibly, transparently, and fairly, then they will also consider the political process to be responsive, transparent, and fair. Thus, evaluations of political actors not only directly influence people's trust in government but might also influence another effective trust reason: people's evaluations of the political process. That dynamic prompts our third hypothesis:

> H3: The effect of using traditional media to access political information on trust in government is mediated first by evaluations of politicians and second by evaluations of the political process.

The serial mediation model shown in Figure 1 illustrates the relationship of the theoretical arguments and empirical findings discussed thus far.

\section{Methods and data}

\subsection{Survey}

To examine how the use of traditional media affects trust in government with cross-sectional data, we conducted an online survey using a nationwide online 
Figure 1: Conceptual serial mediation model explaining the impact of $\mathrm{c}$ on trust in government

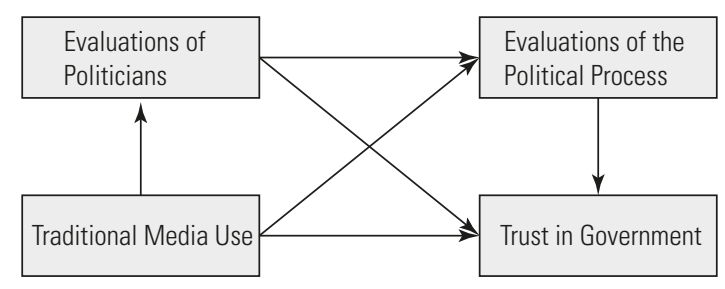

access panel in Germany administered by Respondi AG. The average interview length was 14 minutes.

\subsection{Fieldwork and sample}

Respondi recruits survey respondents on- and offline using a multichannel method (Respondi, 2016). Each panelist double-opted in to participating by completing an online registration form and activating an account. For nine days in August 2016, we gathered 1329 completed questionnaires. Next, we cleaned the dataset regarding the time that respondents spent on completing questionnaires. Respondents who answered all survey questions in fewer than 5 minutes were excluded from analyses, given extensive pretesting indicating the high improbability that they completed their questionnaires carefully in so little time. Second, we identified respondents who simply clicked through the item batteries of the independent variable, the two mediator variables, and the dependent variable. After applying those filtering processes, we identified 1115 respondents to include in statistical analyses. According to the standards of the American Association for Public Opinion Research, our study achieved a response rate of 0.604 (Response Rate 2, American Association for Public Opinion Research, 2016).

Having conducted an online survey, we applied a quota system to match our sample to the German population of internet users ( $M=44.9$ vs. $M=43.7)$ in terms of gender (47.1\% women compared to $47.6 \%$ ) and education (37.9\% A levels compared to $37.1 \%$; (Frees \& Koch, 2015; GLES, 2015).

\subsection{Measures}

For the purpose of our study, we constructed an independent variable, two mediating variables, a dependent variable, and several control variables.

Trust in Government (Dependent Variable). We conceive trust in government as a function of a person's expectations of the national government's ability to provide favorable outcomes. Accordingly, we measured trust in government using a two-step procedure. First, we asked respondents to rate the favorability of 11 different policy outcomes on a seven-point Likert scale ( $1=$ not favorable at all, $7=$ very favorable): preserve peace in Europe and the world $(M=6.57, S D=1.00)$, protect jobs and economic wealth $(M=6.21$, $S D=1.09)$, ensure internal security and public order $(M=6.40, S D=1.01)$, protect the environment and nature $(M=6.04$, $S D=1.22$ ), ensure individual freedom $(M=5.94, S D=1.19)$, reduce social inequalities $(M=5.99, S D=1.25)$, provide sufficient pensions $(M=6.24, S D=1.13)$, integrate migrants into German society ( $M=4.79, S D=1.96)$, accomplish the energy transition $(M=5.32, S D=1.54)$, provide a well-functioning educational system $(M=6.22, S D=1.06)$, and foster European cohesion $(M=5.07, S D=1.84)$. We excluded four items not considered to be highly favorable (i.e., received average scores of less than 6.0) from the second step of measuring trust in government. In the second step, we asked respondents to rate their confidence in the German national government's near-future achievement of the 11 policy outcomes on a seven-point Likert scale $(1=$ not sure at all, $7=$ very sure $)$. We 
used the remaining seven items from the first step to form a mean index $(\alpha=0.94$, $M=3.65, S D=1.46$ ).

Use of Traditional Media (Independent Variable). Using traditional media to access political information was measured with eight items. We formed a consistent mean index $(\alpha=0.76)$ encompassing four items addressing the use of print media, including their online editions, as well as three items addressing the use of TV and one item addressing the use of radio. The question asked on how many days in a typical week respondents read, watched, or listened to articles or news programs about politics or the government in seven types of media: regional newspapers or their respective online editions, nationwide newspapers or their respective online editions, magazines or weekly newspapers or their respective online editions, newsstand newspapers or their respective online editions, public broadcasting channels, private broadcasting channels, and the radio. The eighth item addressed the general use of political TV programs such as political talk shows or political satires. Responses were given on an eightpoint Likert scale $(1=$ never, $8=$ every day; $M=3.54, S D=1.53$ ).

Evaluations of Politicians (Mediating Variable). To measure perceptions of national politicians, we formed a consistent mean index with 16 items $(\alpha=0.91)$ used in the German Longitudinal Election Study. The 16 items consisted of seven subdimensions: autonomy (two items), nonpartisanship (two items), leadership (three items), integrity (three items), benevolence (two items), responsiveness (two items), and likeability (two items). Table 1 in the appendix presents the exact wording of the items. Respondents gave their answers on a seven-point Likert scale $(1=$ totally disagree, $7=$ totally agree; $M=2.91, S D=1.06$ ).

Evaluations of the Political Process (Mediating Variable). Various researchers have identified four major criteria to evaluate political processes: transparency (Klingemann \& Fuchs, 1995), responsiveness (Lane, 1988), efficiency (Floss, 2008), and procedural justice (Lind \& Ty- ler, 1988). We measured evaluations of the political process based on those four criteria as subdimensions. We constructed three items to gauge transparency, used a three-item measure (Esaiasson, Kölln \& Turper, 2015) to gauge perceived responsiveness, constructed three items to gauge efficiency, and slightly adapted Besley's (2010) two-item measure to our topic (see exact wording in Table 1 in the appendix) to gauge procedural justice. Respondents were asked to either agree or disagree with each statement on a seven-point scale $(1=$ strongly disagree, $7=$ strongly agree; $M=2.79, S D=1.03)$. After reversing some items, we constructed a consistent mean index with all 11 items $(\alpha=0.84)$.

Control Variables. Researchers have shown that trust in government is influenced by political and social predispositions such as political interests, satisfaction with democracy, perception of the economy, support for governing parties, and social trust (Hetherington \& Rudolph, 2008; Marien, 2011; Meer \& Dekker, 2011; Zmerli \& Newton, 2008). Three items addressed the respondents' interest in German, European, and non-European international political affairs $(\alpha=0.92$, $M=4.61, S D=1.62)$ using a seven-point Likert scale $(1=$ no interest at all, $7=$ strong interest). Their satisfaction with democracy $(M=4.06, S D=1.80$; seven-point Likert scale, $1=$ very unsatisfied, $7=$ very satisfied , their perception of the current state of the economy $(M=4.63, S D=1.58$; seven-point Likert scale, $1=$ very bad, $7=$ very good), and their support for a party currently governing Germany ( $42 \%$ "voted for one of the governing parties") were assessed with single-item questions. Three items previously used in other studies addressed social trust $(\alpha=0.73, M=4.15, S D=1.29)$, measured on a seven-point Likert scale $(1=$ totally disagree, $7=$ totally agree $)$. We also assessed sociodemographic variables (i. e., gender, age, education, and income) with single-item questions. 


\section{Results}

To answer our research question and test our hypotheses, we ran ordinary least squares regression (OLS) models with the use of traditional media as the independent variable and trust in government as the dependent one. The hypothesized mediation effects were tested using the Statistical Package for the Social Sciences (SPSS) add-on PROCESS specifically designed to measure moderation and mediation effects (Hayes \& Preacher, 2014). PROCESS tests indirect effects via bootstrapping, a nonparametric approach to estimate effect sizes that does not require certain "assumptions about the shape of the distributions of the variables or the sampling distribution of the statistic" (Preacher \& Hayes, 2004, p. 722). Preacher and Hayes (2004) suggest using 5000 bootstrap samples to generate $95 \%$ bias-corrected accelerated confidence intervals; if the 95\% confidence interval (two-tailed) of the respective effect excludes zero, then the indirect effect is considered to be significant (see also Hayes, 2017; Hayes \& Preacher, 2014). Bootstrapping methods can be applied to analyses based on OLS regression models as well as structural equation modeling because both types of analysis yield similar results (Hayes, Montoya \& Rockwood, 2017). To account for potential confounding variables, we included the mentioned control variables in the final model. All results are summarized in Figure 2.
The regression model explains $44 \%$ of the variance in trust in government (adjusted $\left.R^{2}=0.438, p \leq 0.001\right)$. In response to our research question, which asks whether media use directly influences trust in government, the positive and highly significant effect of media use shows that it directly influences the dependent variable ( $b=0.107, t=4.22, p \leq 0.001$ ); the more that respondents use media to access political information, the more that they trust the national government. The results additionally suggest that both mediating variables positively affected trust in government and that both predictors have the two strongest effect sizes in the final regression model. We observe that the effect of evaluations of politicians $(b=0.530$, $t=11.01, p \leq 0.001)$ is stronger than the effect of evaluations of the political process $(b=0.263, t=5.42, p \leq 0.001)$. In line with previous empirical findings, satisfaction with democracy $(b=0.077, t=3.27$, $p=0.001$ ) and perception of the economy $(b=0.123, \quad t=4.72, \quad p \leq 0.001)$ both positively affect trust in government. Political interest $(b=-0.106, t=-4.26, \quad p \leq 0.001)$, however, exerts a negative influence on the dependent variable, which indicates that the more interested respondents are in politics, the less that they trust the national government to implement favorable policies. Our results show significant effects for both age $(b=-0.180, t=-2.61$, $p=0.009)$ and gender $(b=0.006, t=2.53$, $p \leq 0.012$ ). The older respondents are, the less they trust the government, although that effect is relatively small. By gender,

Figure 2: Serial mediation model of the impact of using traditional media on trust in government

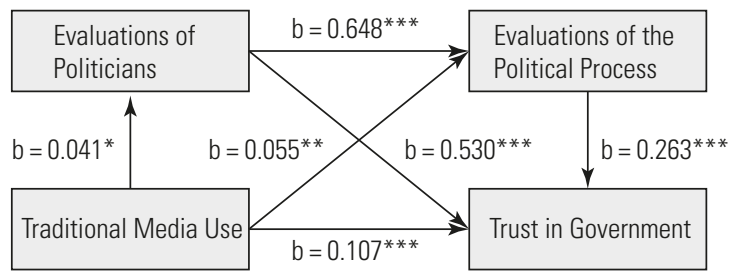

First mediation effect: $b=0.022,95 \% \mathrm{Cl}[0.001,0.049]$. Second mediation effect: $b=0.014,95 \% \mathrm{Cl}[0.004,0.031]$. Serial mediation effect: $b=0.036,95 \% \mathrm{Cl}[0.008,0.070] .{ }^{*} p \leq 0.05 ;{ }^{* *} p \leq 0.01 ;{ }^{* * *} p \leq 0.001$. 
men have more trust than women in the government.

$\mathrm{H} 1$ addressed the indirect effect of media use on trust in government mediated by evaluations of politicians. We computed an OLS regression model using trust in government as the dependent variable, evaluations of politicians as the mediator variable and media use as the predictor variable. All control variables mentioned were also included in analysis. The results indicate that media use positively influence evaluations of politicians $(b=0.041$, $t=1.99, p=0.047$ ), which in turn increases their trust in the government $(b=0.530$, $t=11.01, p \leq 0.001)$. The direct effect of media use on trust in government is mediated by evaluations of politicians $(b=0.022$, BCa CI [0.001, 0.049]), which supports H1.

Concerning the second mediator variable, we ran another OLS regression model with trust in government as the dependent variable, evaluations of the political process as the mediator variable and media use as the independent variable. In line with the assumptions of $\mathrm{H} 2$, media use affects evaluations of the political process ( $b=0.055, t=2.65, p=0.008)$. The results further show that the indirect effect of media use on trust in government mediated by evaluations of politicians is positive and significant $(b=0.014$, BCa CI [0.004, $0.031]$ ). In other words, the more that people use media to access political information, the more highly they evaluate the political process, which in turn prompts increased trust in government.

H3 assumed a serial mediation effect. We hypothesize that the assessment of the second mediator (i.e., evaluations of the political process) is also affected by perceptions of individual politicians. Ultimately, the hypothesized effect of evaluations of politicians on evaluations of the political process is not only positive and highly significant $(b=0.648, t=28.68$, $p \leq 0.001$ ) but also particularly strong. In line with $\mathrm{H} 3$, we therefore detect a significant indirect serial mediation effect ( $b=0.036$, BCa CI $[0.008,0.070])$. That finding underscores the crucial role of personal perceptions of politics in the building trust in government.

\section{Discussion and conclusion}

We conceived trust in government as people's expectations that the government would provide favorable political outcomes. Drawing from literature in sociology and political science, we also conceived evaluations of politicians and of the political process as reasons for trust in government. By introducing a novel reliable measurement for such trust, our results can enrich the theoretical debate about what objects of trust in government encapsulate and their implications for empirical research.

To investigate the media effects on trust in government, we scrutinized at how the use of traditional media to access political information affects the mentioned trust reasons and, accordingly, tested three mediation effects empirically. The results shed light on the importance of news media in democratic societies. Among them, the direct positive impact of media use to access political information on trust in government indicates that expectations regarding the government's ability to deliver favorable outcomes are directly affected by using traditional media. That finding can especially inform current academic debates about media effects on trust in government, for we found no support for the media malaise hypothesis's claim that media use decreases people's trust in government. On the contrary, our results suggest that media use enhances trust in government, which supports the virtuous circle hypothesis. Political news media are often criticized for their (over-) dramatization of political issues (Slattery, Doremus, \& Marcus, 2001; Vettehen, Nuijten \& Beentjes, 2005), and some scholars have even argued that news media coverage has contribute to the electoral success of populist politicians, including U.S. president Donald Trump, by offering them a platform to garner attention (Sides \& Leetaru, 2016). Our results, however, give reason to assume that media use fosters positive effects on political attitudes because it increases the image of political personnel, democratic processes, and trust in the national government. 
Our findings also reveal that using traditional media also indirectly affects trust in government. As we predicted, media use influenced respondents' evaluations of politicians' various character traits, both personal and professional, information about which seems to represent an important means for citizens to form expectations of the national government. Although the personalization of politics has already been extensively discussed in political communication research (Van Aelst et al., 2012), its influence on political trust has not received much attention. In that sense, the finding highlights the particular importance of individual political actors in the political system in general. Giddens (1990, p. 85) argues that individual actors are crucial "access points" to the system in order for trust to be maintained or built up. However, we could not control for the basis of people's evaluations; for instance, it remained plausible that respondents were thinking primarily about certain members of the government while evaluating politicians in general, because certain politicians are more prominently covered by news media. Nevertheless, the finding reflects the great responsibility that politicians bear in representing the political system, for their individual misconduct can erode trust in government as a whole.

Taken together, those findings indicate that traditional media is an important means by which people form opinions and expectations about politics. Despite criticism of the substance of political media content, our results show that news media increase people's assessment of political personnel and processes. Instead of examining the effects of different media separately (e.g., TV vs. newspapers), we used a joint measure to account for the entirety of people's media use. Accordingly, our study opens up avenues for future research to further distinguish different kinds of media repertoires, assuming that people tend to rely on a variety of media outlets. In a sense, investigating the impact of different media repertoires on trust in government could prove to be more fruitful than the common distinction of different media.
That approach could also pave a way to better understand the complementary impact of traditional and digital media (e.g. Yuan, 2011).

We also observe a serial mediation effect: that positive evaluations of politicians increase people's perceptions of political processes, which raises their levels of trust in government. Because concepts such as transparency, responsiveness, effectiveness, and the distributive justice of the political system are complex, in forming opinions people tend to generalize their evaluations of individual political actors to broader political processes. In line with the personalization hypothesis, the serial mediation effect suggests that citizens use politicians as valid indicators when evaluating the quality of procedures in the political system. From another perspective, our results also encourage further investigations into the indirect mediation effects on trust in government in traditional media environments.

The impact of evaluations of politicians on evaluations of political processes in building trust in government seems evident at the national level, given the personalization of media discourses on domestic politics (McAllister, 2007). However, at the supra-national level (e.g., the European Union), an argument for reversed causation can be made. At the level of the European Union, for example, processes of institutions such as the European Commission or the European Parliament receive more attention in media discourses than individual political actors do (Trenz, 2004). For that reason, people are liable to form opinions about lesser-known political personalities based on their evaluations of those institutions and their proceedings. In such cases, the logical order of the two mediators might be reversed.

Before drawing some concluding remarks, we should identify some general limitations of our study. For one, because we relied on cross-sectional data, our statistical analysis based on the OLS regression model could not provide proof regarding the direction of causation. To solidify the causal pathways between the 
variables investigated, additional longitudinal (e.g. Strömbäck et al., 2015) or experimental (Avery, 2009; Mutz \& Reeves, 2005) research designs are needed. However, because our study builds upon a long research tradition in the realm of the media malaise and virtuous circle hypotheses, researchers have largely assumed the direction of causation. Moreover, our study is limited in scope because we draw solely on a German sample. Future comparative research on mediation effects when investigating how media use influences trust in government could enrich literature on the topic and illuminate whether the indirect effects of the mediator variables would succumb to characteristics of the media system, the political system, or both. For instance, the evaluation of political processes might differ between competitive democracies such as Germany and concordance ones such as Switzerland.

Governments require a certain degree of trust from the electorate in order to make decisions about political issues. In our study, we investigated the impact of traditional media use on trust in government, and across the board, we find positive influences of political news media on different political attitudes. Media use encourages better images of politicians and more positive perceptions of different crucial aspects of the democratic process, including transparency, responsiveness, efficiency, and procedural justice. As a result of all of those factors, people tend to be more trusting of the national government when they frequently use mass media to stay informed about public affairs.

\section{References}

AAPOR. (2016). Standard definitions: Final dispositions of case codes and outcome rates for surveys. $8^{\text {th }}$ ed. Retrieved from http:// www.aapor.org/Publications-Media/ AAPOR-Journals/Standard-Definitions. aspx

Aarts, K., Fladmoe, A., \& Strömbäck, J. (2012). Media, political trust, and political knowledge: A comparative perspective. In $\mathrm{T}$. Aalberg \& J. Curran (Eds.), How media in- form democracy: A comparative approach. (pp. 98-118). London: Routledge.

Avery, J. M. (2009). Videomalaise or virtuous circle? The influence of the news media on political trust. The International Journal of Press/Politics, 14(4), 410-433. doi:10.1177/1940161209336224

Balmas, M., \& Sheafer, T. (2013). Leaders first, countries after: Mediated political personalization in the international arena. Journal of Communication, 63(3), 454-475. doi:10.1111/jcom.12027

Baumgartner, J., \& Morris, J.S. (2006). The Daily Show effect. Candidate evaluations, efficacy, and American youth. American Politics Research, 34(3), 341-367. doi:10.1177/1532673X05280074

Bennett, S. E., Rhine, S. L., Flickinger, R.S., \& Bennett, L. L. M. (1999). "Video Malaise" revisited: Public trust in the media and government. The International Journal of Press/Politics, 4(4), 8-23. doi:10.1177/1081180X9900400402

Besley, J.C. (2010). Public engagement and the impact of fairness perceptions on decision favorability and acceptance. Science Communication, 32(2), 256-280. doi:10.1177/1075547009358624

Billiet, J., \& De Witte, H. (1995). Attitudinal dispositions to vote for a "new" extreme right-wing party: The case of "Vlaams Blok." European Journal of Political Research, 27(2), 181-202. doi:10.1111/j.1475-6765.1995.tb00635.x

Bucy, E. P. (2000). Emotional and evaluative consequences of inappropriate leader displays. Communication Research, 27(2), 194-226. doi:0803973233

Camaj, L. (2014). Media use and political trust in an emerging democracy: Setting the institutional trust agenda in Kosovo. International Journal of Communication, 8(1), 187-209.

Cappella, J. N., \& Jamieson, K. H. (1997). Spiral of cynicism. New York: Oxford University Press.

Catterberg, G., \& Moreno, A. (2005). The individual bases of political trust: Trends in new and established democracies. International Journal of Public Opinion Research, 18(1), 31-48. doi:10.1093/ijpor/ edh081 
Ceron, A., \& Memoli, V. (2015). Trust in government and media slant: A cross-sectional analysis of media effects in twenty-seven European countries. The International Journal of Press/Politics, 20(3), 339-359. doi:10.1177/1940161215572634

Citrin, J. (1974). Comment: The political relevance of trust in government. The American Political Science Review, 68(3), 973-988.

Citrin, J., \& Green, D. P. (1986). Presidential leadership and the resurgence of trust in government. British Journal of Political Science, 16(4), 431. doi:10.1017/ S0007123400004518

Citrin, J., \& Luks, S. (1999). Political trust revisited: Déjà vu all over again? In J. R. Hibbing \& E. Theirss-Morse (Eds.), What is it about government that Americans dislike? (pp. 9-27). Cambridge, MA: Cambridge University Press.

Citrin, J., \& Muste, C. (1999). Trust in government. In J. P. Robinson, P. R. Shaver, \& L. S. Wrightsman (Eds.), Measures of political attitudes (pp. 465-532). San Diego, CA: Academic Press.

Easton, D. (1965). A systems analysis of political life. New York: Wiley.

Esaiasson, P., Kölln, A. K., \& Turper, S. (2015). External efficacy and perceived responsiveness - similar but distinct concepts. International Journal of Public Opinion Research, 27(3), 432-445. doi:10.1093/ ijpor/edv003

Floss, D. (2008). Mass media's impact on confidence in political institutions: The moderating role of political preferences a preferences-perceptions model of media effects (No. 28). Challenges to democracy in the $21^{\text {st }}$ century. Retrieved from https://www. uni-muenster.de/imperia/md/content/ kowi/kmg/wp26.pdf

Frees, V. B., \& Koch, W. (2015). Internetnutzung: Frequenz und Vielfalt nehmen in allen Altersgruppen zu. Media Perspektiven, 9, 366-377.

Gamson, W.A. (1968). Power and Discontent. Homewood: Dorsey Press.

Gershtenson, J., \& Plane, D. L. (2007). Trust in government. Retrieved from http://www. electionstudies.org/resources/papers/ Pilot2006/nes011890.pdf
Giddens, A. (1990). Consequences of modernity. Stanford: Stanford University Press.

GLES. (2015). Langfrist-Online-Tracking (Langfrist-Online-Tracking No. 2.0.0).

Grönlund, K., \& Setälä, M. (2007). Political trust, satisfaction and voter turnout. Comparative European Politics, 5(4), 400-422. doi:10.1057/palgrave.cep.6110113

Hasebrink, U., \& Domeyer, H. (2012). Media repertoires as patterns of behaviour and as meaningful practices: A multimethod approach to media use in converging media environments. Participations, 9(2), 757-779.

Hasebrink, U., \& Popp, J. (2006). Media repertoires as a result of selective media use. A conceptual approach to the analysis of patterns of exposure. Communications, 31 , 369-387. doi:10.1515/COMMUN.2006.023

Haumer, F., \& Donsbach, W. (2009). The rivalry of nonverbal cues on the perception of politicians by television viewers. Journal of Broadcasting \& Electronic Media, 53(2), 262-279. doi:10.1080/08838150902907918

Hayes, A. F. (2017). Introduction to mediation, moderation and conditional process analysis. A regression-based approach $\left(2^{\text {nd }}\right.$ edition). New York, London: The Guilford Press.

Hayes, A. F, Montoya, A. K., \& Rockwood, N. J. (2017). The analysis of mechanisms and their contingencies: PROCESS versus structural equation modeling. Australasian Marketing Journal, 25(1), 76-81. doi:10.1016/j.ausmj.2017.02.001

Hayes, A. F., \& Preacher, K. J. (2014). Statistical mediation analysis with a multicategorical independent variable. British Journal of Mathematical and Statistical Psychology, 67(3), 451-470. doi:10.1111/bmsp.12028

Hellweg, S.A., Dionisopoulos, G. , \& Kugler, D. B. (1989). Political candidate image: A state-of-the-art review. In B. Dervin \& M. J. Voigt (Eds.), Progress in Communication Science. Volume IX (pp. 43-78). Norwood, NJ: Ablex Publishing Corporation.

Hetherington, M. J. (2005). Why trust matters: Declining political trust and the demise of American liberalism. Princeton, NJ: Princeton University Press.

Hetherington, M. J. (1998). The political relevance of political trust. The American Political Science Review, 92(4), 791-808. 
Hetherington, M. J., \& Rudolph, T. J. (2008). Priming, performance, and the dynamics of political trust. Journal of Politics, 70(2), 498-512. doi:10.1017/S0022381608080468

Hibbing, J. R., \& Theiss-Morse, E. (1995). Congress as a public enemy: Public attitudes toward American political institutions. Cambridge, MA: Cambridge University Press.

Hooghe, M., \& Marien, S. (2012). A comparative analysis of the relation between political trust and forms of political participation in Europe. European Societies, 15(1), 131-152. doi:10.1080/14616696.2012.692807

Kim, H. G., \& Kim, J. (2012). Comparing the effects of newspaper, TV news, and the internet news on the evaluation of a major political candidate: Latent growth modeling with longitudinal panel data from the 2007 presidential campaign in South Korea. International Journal of Public Opinion Research, 24(1), 62-78. doi:10.1093/ijpor/edr046

Kim, K., \& McCombs, M. (2007). News story descriptions and the public's opinions of political candidates. Journalism \& Mass Communication Quarterly, 84(2), 299-314. doi:10.1177/107769900708400207

Klingemann, H.-D., \& Fuchs, D. (1995). Citizens and the state. Oxford: Oxford University Press.

Kohring, M., \& Matthes, J. (2007). Trust in news media. Development and validation of a multidimensional scale. Communication Research, 34(2), 231-252. doi:10.1177/0093650206298071

Kong, D. T. (2014). Perceived competence and benevolence of political institutions as culturally universal facilitators of political trust: Evidence from Arab countries. Cross-Cultural Research, 48(4), 385-399. doi:10.1177/1069397114523929

Lane, R.E. (1988). Procedural goods in a democracy: How one is treated versus what one gets. Social Justice Research, 2(3), 177-192. doi:10.1007/BF01054555

Levi, M., \& Stoker, L. (2000). Political trust and trustworthiness. Annual Review of Political Science, (3), 475-507. doi:10.1146/annurev. polisci.3.1.475

Lind, E. A., \& Tyler, T. R. (1988). The Social Psychology of Procedural Justice. New York: Springer Science \& Business Media.
Listhaug, O. (1995). The dynamics of trust in politicians. In H.-D. Klingemann \& D. Fuchs (Eds.), Citizens and the State (pp. 261-297). Oxford: Oxford University Press. doi:10.1093/0198294735.003.0009

Lühiste, K. (2006). Explaining trust in political institutions: Some illustrations from the Baltic states. Communist and Post-Communist Studies, 39(4), 475-496. doi:10.1016/j.postcomstud.2006.09.001

Marien, S. (2011). The effect of electoral outcomes on political trust: A multi-level analysis of 23 countries. Electoral Studies, 30(4), 712-726. doi:10.1016/j.electstud.2011.06.015

Marien, S., \& Hooghe, M. (2011). Does political trust matter? An empirical investigation into the relation between political trust and support for law compliance. European Journal of Political Research, 50(2), 267291. doi:10.1111/j.1475-6765.2010.01930.x

McAllister, I. (2007). The personalization of politics. In R. J. Dalton \& H.-D. Klingemann (Eds.), The Oxford Handbooks of Political Science: The Oxford Handbook of Political Behaviour (pp. 571-588). Oxford: Oxford University Press.

Miller, A. H. (1974). Political issues and trust in government: 1964-1970. The American Political Science Review, 68(3), 951-972.

Miller, A. H., \& Borrelli, S. (1991). Confidence in government during the 1980s. American Politics Quarterly, 19(2), 147-173.

Miller, A.H., \& Listhaug, O. (1990). Political parties and confidence in government: A comparison of Norway, Sweden and the United States. British Journal of Political Science, 20(3), 357. doi:10.1017/ S0007123400005883

Moy, P., \& Pfau, M. (2000). With malice toward all? The media and public confidence in democratic institutions. Westport, CT: Prager Publishers.

Moy, P., Pfau, M., \& Kahlor, L. (1999). Media use and public confidence in democratic institutions. Journal of Broadcasting \& Electronic Media, 43(2), 137. doi:10.1080/08838159909364481

Moy, P., \& Scheufele, D.A. (2000). Media effects on political and social trust. Journalism \& Mass Communication Quarterly, 77(4), 744-759. doi:10.1177/107769900007700403 
Mutz, D. C., \& Reeves, B. (2005). The new videomalaise: Effects of televised incivility on political trust. American Political Science Review, 99(1), 1-15. doi:10.1017/ S0003055405051452

Norris, P. (2000). A virtuous circle: Political communication in post-industrial societies. New York: Cambridge University Press.

Owen, D., \& Dennis, J. (2001). Trust in federal government: The phenomenom and its antecedents. In J. R. Hibbing \& E. Theiss-Morse (Eds.), What Is It About Government That Americans Dislike? (pp. 209226). Oxford: Oxford University Press.

Pauwels, T. (2011). Explaining the strange decline of the populist radical right Vlaams Belang in Belgium: The impact of permanent opposition. Acta Politica, 46(1), 60-82. doi:10.1057/ap.2010.17

Pietsch, J., \& Martin, A. (2011). Media use and its effect on trust in politicians, parties and democracy. Australasian Parliamentary Review, 26(1), 131-141.

Preacher, K. J., \& Hayes, A. F. (2004). SPSS and SAS procedures for estimating indirect effects in simple mediation models. Behavior Research Methods, Instruments, \& Computers, 36(4), 717-731. doi:10.3758/ BF03206553

Respondi. (2016). Panelbook. Retrieved from http://www.respondi.com/wp-content/ uploads/2016/09/DE_Panelbook_respondi_kl.pdf.

Robinson, M. J. (1976). Public affairs television and the growth of political malaise: The case of "The Selling of the Pentagon." The American Political Science Review, 70(2), 409-432.

Sadri, H., \& Flammia, M. (2014). Democracy, political perceptions, and new media. Journal of Systemics, Cybernetics and Informatics, 12(3), 29-33. Retrieved from http://www.iiisci.org/Journal/CV\$/sci/ pdfs/HB354MJ14.pdf

Seyd, B. (2015). How do citizens evaluate public officials? The role of performance and expectations on political trust. Political Studies, 63(S1), 73-90. doi:10.1111/14679248.12163

Shaffer, S. D. (1981). A multivariate explanation of decreasing turnout in presidential elections , 1960-1976. American Journal of Political Science, 25(1), 68-95.
Sides, J., \& Leetaru, K. (2016). A deep dive into the news media's role in the rise of Donald J. Trump. Washington Post. Retrieved from https://www.washingtonpost.com/news/ monkey-cage/wp/2016/06/24/a-deepdive-into-the-news-medias-role-in-therise-of-donald-j-trump/

Slattery, K., Doremus, M., \& Marcus, L. (2001). Shifts in public affairs reporting on the network evening news: A move toward the sensational. Journal of Broadcasting \& Electronic Media, 45(2), 290-302. doi:10.1207/s15506878jobem4502

Strömbäck, J., Djerf-Pierre, M., \& Shehata, A. (2015). A question of time? A longitudinal analysis of the relationship between news media consumption and political trust. The International Journal of Press/Politics, 1940161215613059-. doi:10.1177/1940161215613059

Taneja, H., Webster, J. G., Malthouse, E. C., \& Ksiazek, T. B. (2012). Media consumption across platforms: Identifying user- defined repertoires. New Media \& Society, 14(6), 951-968.

Torcal, M. (2014). The decline of political trust in Spain and Portugal: Economic performance or political responsiveness? American Behavioral Scientist, 58(12), 15421567. doi:10.1177/0002764214534662

Trenz, H.-J. (2004). Media coverage on European governance. European Journal of Communication, 19(3), 291-319. doi:10.1177/0267323104045257

Tsfati, Y., Tukachinsky, R., \& Peri, Y. (2009). Exposure to news, political comedy, and entertainment talk shows: Concern about security and political mistrust. International Journal of Public Opinion Research, 21(4), 399-423. doi:10.1093/ijpor/edp015

Ulbig, S. G. (2008). Voice is not enough. Public Opinion Quarterly, 72(3), 523-539. doi:10.1093/poq/nfn030

Valentino, N.A., Beckmann, M.N., \& Buhr, T.A. (2001). A spiral of cynicism for some: The contingent effects of campaign news frames on participation and confidence in government. Political Communication, 18(4), 347-367. doi:10.1080/10584600152647083

Van Aelst, P., Sheafer, T., \& Stanyer, J. (2012). The personalization of mediated political communication: A review of 
concepts, operationalizations and key findings. Journalism, 13(2), 203-220. doi:10.1177/1464884911427802

Van Der Meer, T., \& Dekker, P. (2011). Trustworthy states, trusting citizens? A multilevel study into objective and subjective determinants of political trust. In S. Zmerli \& M. Hooghe (Eds.), Political Trust. Why Context Matters (pp. 95-116). Colchester: ECPR Press.

Vettehen, P.H., Nuijten, K., \& Beentjes, J. (2005). News in an age of competition: The case of sensationalism in Dutch television news, 1995-2001. Journal of Broadcasting \& Electronic Media, 49(3), 282-295. doi:10.1207/ s15506878jobem 4903

Wong, T. K.-y., Wan, P.-s., \& Hsiao, H.-H.M. (2011). The bases of political trust in six Asian societies: Institutional and cultural explanations compared. International Political Science Review, 32(3), 263-281. doi:10.1177/0192512110378657

Yuan, E. (2011). News consumption across multiple media platforms. Information, Communication \& Society, 14(7), 998-1016. doi:10.1080/1369118X.2010.549235

Zmerli, S., \& Newton, K. (2008). Social trust and attitudes toward democracy. Public Opinion Quarterly, 72(4), 706-724. doi:10.1093/ $\mathrm{poq} / \mathrm{nfn} 054$ 


\section{Appendix}

\section{Table 1: Questionnaire items for the mediator variables evaluations of politicians and evaluations of the political process}

\begin{tabular}{|c|c|}
\hline Evaluations & Wording of the questions and items \\
\hline Evaluations of Politicians & $\begin{array}{l}\text { "When you think of our leading politicians in Berlin, how much do you agree with the } \\
\text { following statements?" }\end{array}$ \\
\hline Autonomy1 & "Politicians are puppets of big business." \\
\hline Autonomy2 & "Politicians dare to fight people in power." \\
\hline Nonpartisanship1 & "Politicians are able to overcome partisan bias." \\
\hline Nonpartisanship2 & "Politicians represent the opinion of their parties only." \\
\hline Leadership1 & "Politicians have personalities suited to leadership." \\
\hline Leadership2 & "Politicians follow up their words with actions." \\
\hline Leadership3 & "Politicians are able to decide quickly and with confidence." \\
\hline Integrity1 & "Politicians are sincere people." \\
\hline Integrity2 & "Politicians are reliable people." \\
\hline Integrity3 & "Politicians pursue their own interests only." \\
\hline Benevolence1 & "Politicians fight for social justice." \\
\hline Benevolence2 & "Politicians are people like you and me." \\
\hline Responsiveness1 & "Politicians are aware of the problems that regular citizens face." \\
\hline Responsiveness2 & "Politicians consider the opinions of citizens." \\
\hline Likeability1 & "Politicians are likable people." \\
\hline Likeability2 & "Politicians have positive charisma." \\
\hline Evaluations of the political Process & $\begin{array}{l}\text { "Now, we have some questions about your impression of the political system in } \\
\text { Germany. How much do you agree with the following statements?" }\end{array}$ \\
\hline Transparency1 & "Citizens do not know which direction Germany is headed because nobody tells them." \\
\hline Transparency2 & "Citizens do not participate in politics because they lack the necessary information." \\
\hline Transparency3 & "German politics try to keep citizens informed." \\
\hline Responsiveness1 & "Government and parliament inform themselves about the wishes of citizens." \\
\hline Responsiveness2 & "Government and parliament try to satisfy the wishes of citizens." \\
\hline Responsiveness3 & "Government and parliament explain their policies to citizens." \\
\hline Efficiency1 & "In politics, addressing urgent problems is often postponed." \\
\hline Efficiency2 & "Too much time passes between political decisions and their implementation." \\
\hline Efficiency3 & "Government actions are more expensive than originally calculated." \\
\hline Procedural justice1 & "A citizen's opinions are represented in political decision making." \\
\hline Procedural justice1 & "Before political decisions are made, every citizen has a fair chance to voice complaints." \\
\hline
\end{tabular}

